\title{
POSTCOLONIAL AESTHETICS: AFFECT, AFFECTION OR AFFECTATION?
}

\author{
Faisal Nazir $^{*}$
}

\begin{abstract}
This article analyzes the concept of postcolonial aesthetics as developed and debated by such critics as Bill Ashcroft, Elleke Boehmer and Robert Young. In particular, it critiques Ashcroft's theorization of the postcolonial aesthetics in his article 'Towards a Postcolonial Aesthetics' and recommends an alternative approach to the conceptualization of postcolonial aesthetics with reference to Muhammad Hasan Askari's essay on Ahmed Ali's novel Twilight in Delhi. It questions Ashcroft's emphasis on the hybrid linguistic makeup of the postcolonial text as the source of the particular aesthetic effects of the text and emphasizes the need for differentiating between affection - the writer's deep sense of engagement with and involvement in the narrative - and affectation - a clever use of native words and expressions by the writer to authenticate his or her cultural identity - in discussing the affective dimension of a postcolonial text. The article argues that the aesthetic impact of the postcolonial text is produced by the intensity of experience and emotional involvement of the postcolonial writer (affection) as opposed to being produced by creative wordplay and mixing of local and foreign languages (affectation). Thus, the article contributes to the ongoing debates about the aesthetic dimension of postcolonial literature.
\end{abstract}

Keywords: Aesthetics, affect, affection, affectation, hybridity, postcolonial

\section{Introduction}

In recent years, critical interventions by some major postcolonial critics have opened up a debate about the significance of aesthetics in postcolonial literature and criticism. Elleke Boehmer and Bill Ashcroft have explored the possibility of developing a specifically postcolonial aesthetics while Robert Young has expressed skepticism regarding this idea. In this article I engage with the views of these critics and propose an alternative way of conceptualizing postcolonial aesthetics. In particular, I develop my concept of postcolonial aesthetics in contrast to and through a critique of Bill Ashcroft's concept. Aschroft defines postcolonial aesthetics as a "transformative affective space" constituted by the hybridity of the language of the postcolonial literary text. I argue that the affective force of a postcolonial literary text arises out of the intensity of cultural experience represented in the text and not from mere linguistic creativity cleverly displayed in mixing of tongues. Building upon this argument, I define postcolonial aesthetics as constituted by affection - a writer's deep sense of attachment to and involvement in his or her culture - and not by affectation - an artificial and superficial mixing of languages in the postcolonial texts. I first discuss the views of Boehmer, Ashcroft and Young on postcolonial aesthetics, and then critique Ashcroft's concept of the postcolonial aesthetics and present an alternative way of conceptualizing postcolonial aesthetics with reference to Hasan Askari's commentary on Ahmed Ali's novel Twilight in Delhi.

\section{Aesthetics and Postcolonial Literature}

Though the aesthetic aspect of postcolonial literature has been given significant critical attention only in recent years, the question of aesthetics has always been central to the study of postcolonial literature. In a sense, 'postcolonial literature' is as much an aesthetic term as it is a political one. By postcolonial literature is meant not just literature that offers political resistance to colonialism and imperialism in its content but a literature

\footnotetext{
* Faisal Nazir, Ph.D. Assistant Professor, Department of English, University of Karachi
} 
that challenges colonial domination in and through its very form. Written in the language of the colonizer, postcolonial literature challenges the linguistic and literary norms of the colonizer and offers resistance to colonial ideology through its formal creativity and innovation. Postcolonial literature not only reshapes and restructures the narrative models of European literature but also reshapes and restructures the language in which the literature is produced. This is not just a 'literary' technique, a clever play with words, but is rather a way of infusing the English language with the cultural difference of the writer and the writer's nation or community.

It was on this basis that a number of early postcolonial critics argued for a different critical approach to postcolonial literature than was being applied to it in early years of its development. Critics like Chinua Achebe claimed that European literary criticism was 'colonialist' in the sense that it regarded postcolonial literature as a minor branch of British literature and not as a literature in its own right. ${ }^{1}$ In other words, the critics demanded that postcolonial literature, though written in European languages, needs to be read differently from the way European literature is read because postcolonial literature has its own distinct aesthetic and ideological makeup. It was as a result of these arguments that the earlier term 'commonwealth literature' was discarded in favour of 'postcolonial literature' which was considered as more appropriate to the distinct nature and function of this 'new' literature than the former term.

Thus, the term 'postcolonial' has always indicated not just a politics but also an aesthetics. While it has long been understood that postcolonial literature has a specific aesthetic aspect, a few critics have recently attempted to theorize the "postcolonial aesthetic'. Elleke Boehmer in her article "A Postcolonial Aesthetic" has attempted to identify the main elements constituting the postcolonial aesthetic. ${ }^{2}$ Boehmer first describes what she means by a specifically 'postcolonial' aesthetic. "Is there a postcolonial writing," she asks, "to which the label aesthetically postcolonial might stick more closely?" "Our search is for an aesthetic method," she further elaborates, "that might allow us to refer to some of the different types of postcolonial writing as characteristically and hence recognizably postcolonial, as preoccupied with a shared, even if a widely disseminated, aesthetic." ${ }^{3}$ The main problem in formulating a postcolonial aesthetic, according to Boehmer, is that political approaches dominate the reading of postcolonial literature since the term 'postcolonial' is interpreted exclusively as a political term. Boehmer goes on to discuss various theorizations of the postcolonial aesthetic with reference to writers and critics including Homi Bhabha, Edward Said, Ato Quayson and Ben Okri, and formulates her own view of the postcolonial aesthetic mainly upon the works of Quayson and Okri. She offers the following definition of the postcolonial aesthetic towards the end of her article:

Perhaps there is that within a postcolonial aesthetic that clarifies or sheds light on the postcolonial condition, be it hybrid or Manichean, though without necessarily setting out to do so, without overt intention, without set and specific interest. There is that within an aesthetic that we might call postcolonial that draws in the postcolonial world, imbibes its affect, and constellates and reconstellates its meanings through our reading of it, our participation in it ... there is that within an aesthetic which we might want to call postcolonial, that catalyses a post-humanist or non-western humanism, though again this effect is largely incidental - the process plays itself out with mostly unanticipated consequences. ${ }^{4}$

\footnotetext{
${ }^{1}$ Chinua Achebe, "Colonialist Criticism," in Critical Theory Since Plato: Revised Edition, ed. Hazard Adams (Orlando, FL: Harcourt Brace Jovanovic, Inc. 1992), pp.1190-1198

${ }^{2}$ Elleke Boehmer, "A Postcolonial Aesthetic: Repeating Upon the Present," in Rerouting the Postcolonial: New Directions for the New Millennium, eds. Janet Wilson, Cristina Sandru and Sarah Lawson Welsh, (London and New York: Routledge, 2010), pp.170-181

${ }^{3}$ Boehmer, "A Postcolonial Aesthetic," p.174

${ }^{4}$ Ibid., p.180; italics in the original.
} 
Like Bill Ashcroft, whose views on postcolonial aesthetics will be discussed later in the article, Boehmer emphasizes the centrality of language to any discussion of the postcolonial aesthetic. "The postcolonial aesthetic," she writes, "then, is in language rather than of language, it requires participation from readers, it draws us into a process that makes possible certain kinds of postcolonial understanding." "Like other kinds of aesthetic," Boehmer further states, "it allows us to interrogate, and, as compensation to our questioning selves, tell stories about, the mystery that is not so much the Other, generically speaking, as the ultimately unknowable other human being."

Boehmer has used this rather indirect way of defining the postcolonial aesthetic because, as she states, her focus is on "what a postcolonial aesthetic might do rather than [on defining] what it is" since "it may be nothing at all." In other words, Boehmer tries to develop a definition of the postcolonial aesthetic on the basis of the perceived impact of the postcolonial text upon the readers. The postcolonial text affects the readers in specific ways and elicits an emotional, ethical and intellectual response from the reader. Thus, the postcolonial aesthetic does not simply make a sensuous appeal upon the reader but also gets the reader to intellectually and ethically engage with the postcolonial world. And it is the language of the postcolonial text that affects the reader in this way and makes him or her conscious of the otherness of the material he or she is dealing with. The aesthetic impact of the postcolonial text is distinct from its political impact, though it may support and enhance the political impact. While the political impact is very much intentioned by the postcolonial writer, the aesthetic affect is not the result of a 'palpable design upon the reader', in the famous words of John Keats, but is in the very nature of the language of the postcolonial text, reading which affects the reader in the multiple ways noted above.

It is in Bill Ashcroft's views on postcolonial aesthetics that this role of the language of postcolonial text is further elaborated. Emphasizing the fact that the postcolonial text is produced and consumed in a variety of cultural contexts, Ashcroft defines the postcolonial text as a "contact zone" "which is a space of negotiation, a heterotopic space in which the boundary between self and other blurs, a space in which meaning is negotiated, where, in a sense, both writer and reader are changed in constitutive collusion." The hybridity of the postcolonial text produces a specifically "postcolonial aesthetics" which, for Ashcroft, "refers to a mutually transformative affective space that may accompany or be interwoven with the meaning event." ${ }^{8}$ However, the hybridity of the postcolonial text and its aesthetic impact is not to be looked for in the thematic content or the narrative structure of the text, but in the very language of the postcolonial text. Composed in a European language by a non-European writer and read by readers from various cultural backgrounds, including European and American cultures, the postcolonial text displaces both the producer and the consumer, the writer and the reader, from their settled positions within their cultures and brings them into an unsettling contact with each other, leading to a mutual cultural transformation. According to Ashcroft, "This aesthetic transformation goes hand in hand with a cultural transformation, and, as with many other aspects of postcolonial transformation, the primary model for it is language.. ${ }^{9}$ Referring to the two interpretations of aesthetics aesthetics as ideology and aesthetics as stimulus - in Western philosophy and literary criticism, Ashcroft argues that skepticism towards aesthetics as an element in literary criticism is based on the exclusive interpretation of aesthetics as ideology. In his opinion, aesthetics becomes an acceptable concept in literary criticism if interpreted in terms of sensory stimulus. ${ }^{10}$

\footnotetext{
${ }^{5}$ Ibid.

${ }^{6}$ Ibid.

${ }^{7}$ Bill Ashcroft. "Towards a Postcolonial Aesthetics," Journal of Postcolonial Writing 51, no. 4 (2015), p.411

${ }^{8}$ Ibid., italics original

${ }^{9}$ Ibid., p.414

${ }^{10}$ Ibid.
} 
In Ashcroft's view, the language of the postcolonial text produces an aesthetically and culturally transformative impact through its physical or material construction. Ashcroft comes up with the concept of the "material resonance" of the language of the postcolonial text to define this transformative impact of the text. "The "postcolonial" aesthetic," according to Ashcroft, "lies in the materiality of the language, for this is the space of contact between cultures." 11 The language of the postcolonial text, usually a European language, carries the tone and the rhythm of the native language of the postcolonial writer and in that way makes the European reader conscious of cultural difference. However, it also maintains the linguistic conventions of the European language sufficiently to make the reader acknowledge and accept it as a part of his or her cultural context. "This dialectic," states Ashcroft, "is the essential feature of the literature of linguistic intersection, and its particular facility in this context is its capacity to intimate a cultural reality through the music, the "bodily presence" of the words."12 This cultural reality communicated through the materiality of the language of the postcolonial text strikes the reader in a more forceful way than does the cultural reality represented by the meaning of the text. The materiality of language constitutes what Ashcroft calls "presence effects" of the text which are distinct from the "meaning effects" of the text. The materiality of language gives cultural difference a physical presence and thus makes the otherness of other cultures resistant to any reassuring and normalizing interpretative framework brought to bear upon it by the foreign reader. The concept of "material resonance" allows us to understand "that that there are ways of experiencing, responding to, of "understanding" the world apart from structures of meaning, that is, apart from the kind of interpretation that can be fixed in language." ${ }^{.13}$ In this sense then, "material resonance ... is a constant invitation to openness, to anticipation, to an expectation of the wonder of the world available through the eyes of the other." Ashcroft concludes emphatically that "material resonance is the path to a postcolonial aesthetics." "14

This is a very interesting and important contribution to the discussion of postcolonial aesthetics. Unlike Boehmer's, it is more assertive and clearly and emphatically articulated. While Boehmer restricts herself only to suggesting where to look for a postcolonial aesthetic - in the language of the postcolonial text - Ashcroft goes further and identifies what element in the language of the postcolonial text produces a specific aesthetics. However, while these two critics have tried to define a specifically postcolonial aesthetic, Robert Young is skeptical of the idea of a postcolonial aesthetic, though he acknowledges that postcolonial literature as a form of art does have an aesthetic aspect which is important to highlight in discussing postcolonial literature. In his view, postcolonial writing is very rich and diverse and the only way a postcolonial aesthetic can be defined is by reducing all postcolonial literature to a single definition of postcolonial writing. "But I don't think there is one postcolonial aesthetic," he argues in an interview on the topic of postcolonial aesthetics, "and I don't think that would work unless you want to classify or characterize the postcolonial in some particular way so as to make it homogeneous enough to produce a particular aesthetic."15 "The postcolonial," he continues, "is all about diversity, after all, so that must apply to its aesthetics as to everything else. There are many different ways in which writing can involve forms of critique and resistance." 16

Young, however, does not deny the importance of addressing the question of aesthetics in postcolonial literature, but, on the contrary, "does approve of the idea of foregrounding the aesthetic, that is to say the literary and linguistic qualities of the writing."

\footnotetext{
${ }^{11}$ Ibid., p.415

${ }^{12}$ Ibid.

${ }^{13}$ Bill Ashcroft, "Towards a Postcolonial Aesthetics," p.419

${ }^{14}$ Ibid.

${ }^{15}$ Catherine Noske, “A Postcolonial Aesthetic? An Interview with Robert Young," Journal of Postcolonial Writing 50, no.5 (2014), p.613

${ }^{16}$ Ibid.

${ }^{17}$ Ibid.
} 
view, a lack of emphasis on aesthetics has allowed some of the writers to produce what he calls "social science fiction", fiction which relies upon detailed cultural descriptions and exoticism to attract the foreign readers. If the reader already knows the cultures being described in these texts, he or she finds the books uninteresting because they are merely "content-based" and have very little aesthetic merit. In fact, so conventional has become this "anthropological" approach in postcolonial fiction that "sometimes you feel, when books come out, that as long as they touch the right buttons in terms of giving you a cultural description of such and such a group, and then staging some of the issues, the conflicts that arise of being that group in a particular environment, then it ticks all the right boxes and therefore the book gets read and appreciated." ${ }^{\prime 18}$ For this reason it is important that there should be "aesthetic evidence for why some novelists are actually more powerful and richer than other writers" and "why their novels are more substantial than others." ${ }^{19}$ Thus, while disapproving the idea of a postcolonial aesthetic, Young strongly asserts his belief in the importance of evaluating aesthetic merits of literary texts in literary criticism.

\section{The Language of Postcolonial Literature}

In this critique of the concept of the postcolonial aesthetic, the central problem Young has identified is that to obtain a definition of the postcolonial aesthetic, a prior definition of the postcolonial is needed. How one defines the postcolonial aesthetic depends upon how one defines the postcolonial. This means that defining a postcolonial aesthetic means imposing a single hegemonic definition upon postcolonial literature and reducing its richness and diversity. It is, perhaps, for this reason that Boehmer remains guarded and tentative about defining the postcolonial aesthetic in her article. However, in "Towards a Postcolonial Aesthetics", Ashcroft quickly settles the issue of the political element in postcolonial literature and focuses exclusively on the concept of aesthetics. In Ashcroft's view, postcolonial texts are transcultural texts that bring different cultures into contact with each other in a spirit of "constitutive collusion." 20 They thus constitute a contact zone which is more a "constructive" than a "contestatory" space, a space that facilitates negotiation and interaction between different cultures leading to mutual understanding and respect. In this way, Ashcroft rather hastily reduces the political realities of the postcolonial world to one particular perspective. This poststructuralist and postmodernist perspective, associated mainly with the name of Homi Bhabha, has dominated postcolonial theory and criticism from the earliest days of this critical discourse and has been criticized by many critics from different political and cultural perspectives. In particular, the pro-globalization drift of this perspective has led many critics to question its validity. Boehmer herself has criticized this particular reading of the politics of postcolonial literature and has defined it as a "neo-Orientalist" approach to postcolonial literature. In her view, the "neo-Orientalism" of this approach is evident in the "enthusiastic exoticizing (and often also feminizing) vocabulary of postcolonial literary critiques: an 'Arabian Nights' exegetic language which lays emphasis on the narrative magic, verbal richness, and marvelous crowdedness of postcolonial texts, and is tied in with an institutional interest in privileging migrant, multivocal, Rushdiesque (and usually Indian or Indian subcontinent) writing as most vividly demonstrating that exotic otherness. $" 21$

Opposed to this postmodernist, pro-globalization slant in postcolonial theory are the more materialist and historicist approaches in the theory. These approaches highlight the inequalities and injustices that prevail in the contemporary world and identify and critique the economic and political, as well as discursive structures that facilitate this

\footnotetext{
${ }^{18}$ Ibid., p.614

${ }^{19} \mathrm{Ibid}$.

${ }^{20}$ Ashcroft, Op.Cit. p.411

${ }^{21}$ Boehmer, "Questions of Neo-Orientalism," Interventions: International Journal of Postcolonial Studies 1, no. 1 (1998), p.18.
} 
exploitation of the many by the few. Postcolonial theory and postcolonial literature, from this materialist and historicist perspective, articulate and bring to light the plight of the oppressed from around the world. According to Robert Young, "The postcolonial has always been concerned with interrogating the interrelated histories of violence, domination, inequality, and injustice, with addressing the fact that, and the reasons why, millions of people in this world still live without things that most of those in the West take for granted." ${ }^{22}$ It is from this pain and suffering that postcolonial literature draws its intensity and affective force. If the language of postcolonial literature displays marks of hybridity and cross-cultural interaction, it is only to emphasize "the pain of history words contain" 23 and the loss as well as the gain that colonialism has imposed upon its victims. Creolization, linguistic and cultural, has not been the smooth and peaceful process in the formerly colonized and the currently globalized regions of the world that it is made out to be in some versions of postcolonial theory. What Ashcroft interprets as a sign of "constitutive collusion" is far from a very pleasant experience for the postcolonial writer writing in a foreign language. In Young's view, the language of the postcolonial text "is a site of anxiety because of having to choose between different languages, and not having that immediate relation to a particular language as the language in which you speak, write and publish without even having to think about it." ${ }^{24}$ The language of postcolonial literature displays the "brutal effect of history on a colonized culture." 25 Thus, according to Young, "postcolonial literature is haunted by the question of language: of whose language, whose voice."26

Simona Bertacco has also highlighted the various literary and linguistic innovations postcolonial writers use to convey the injustice and inequality they have inherited from colonialism. Acknowledging that "the postcolonial text has quite consistently been valued more for its supposed political message than for its formal excellence," Bertacco asserts that through its formal innovation postcolonial literature redefines "what is or could be considered literature, what criteria should guide the evaluation of meaning and excellence, and how indebted even these notions are to the Western literary tradition." 27 There are two ways, according to Bertacco, that postcolonial texts mediate between different cultures: "thematically, by foregrounding the figures of interpreters and translators, larger-than-life characters living between different imaginative and cultural worlds, stylistically, by developing sophisticated techniques of code switching, by translating or mixing languages in the same sentence, by letting interferences from one language affect their way of using the other, and so forth." 28 "When these techniques are used in literature," Bertacco further comments, "language steps out of its ordinary function and becomes exhibitionist and intensive - in other words, unfamiliar., ${ }^{29}$

To illustrate the functioning of language in postcolonial literature, Bertacco discusses the works of two Canadian writers of West Indian background, Marlene Nourbese Philip and Dionne Brand, and highlights how these writers challenge the dominant ideology through their stylistic innovations. In particular, she comments on the work of Marlene Nourbese Philip and explains the linguistic strategies the poet has used to express the complexity of her relation to the English language in which she writes. According to Bertacco, Philip's poetry "is an instance of a deconstructive poetics, a poetics that literally chews up the literary vocabularies of different traditions and different places, and articulates, through a physically laborious process that is captured on the page, its own struggle to ground

\footnotetext{
${ }^{22}$ Robert Young, "Postcolonial Remains," New Literary History, 43, no. 1 (2012), p.20.

${ }^{23}$ Derek Walcott, "The Schooner Flight", Collected Poems 1948-1984, (New York: Farrar, Straus and Giroux), pp.345-362

${ }^{24}$ Noske, Op.Cit., p.615

${ }^{25}$ Ibid.

${ }^{26}$ Ibid.

${ }^{27}$ Simona Bertacco, "Postcolonialism," in The Oxford Handbook of Philosophy and Literature, ed. Richard Eldridge, (New York: Oxford University Press, 2009), p.327.

${ }^{28}$ Ibid.

${ }^{29}$ Ibid.
} 
meaning in history and place." ${ }^{, 30}$ Bertacco discusses Philip's poem "Discourse on the Logic of Language" and shows how language, instead of being a pleasurable tool of cultural mediation as Ashcroft describes it to be, expresses the cultural conflict the writer has experienced and how this conflict and the suffering it entails are embodied in the language of the poem. The formal innovation does not remain limited to language in this poem but the very layout and discursive makeup of the poem are also used to deconstruct conventional notions of identity and culture. With a creative use of layout, the poem displays a variety of discourses present against each other on the same page. In this way, "Philip goes a long way to disrupt the conventional space of the poem and to turn the language of the poem into the embodiment, the written mark, of a very physical pain." ${ }^{31}$ Because of its complex layout, the poem requires us to change our position to read the various passages placed in different parts of the page, and through this strategy, "Philip is articulating a poetics that recognizes and exploits the sensuous potential of words." 32 The "material resonance" of a postcolonial text is, therefore, not any pleasant music arising out of the harmonious mingling of cultures, but is rather a jarring and discordant cry against injustice, inequality and suppression.

\section{The Postcolonial Aesthetic or the Postcolonial Exotic?}

From this perspective, then, Ashcroft's characterization of the postcolonial aesthetics as a "transformative affective space" also needs to be reconsidered. Ashcroft defines the affective dimension of the postcolonial text as distinct from its semantic and thematic dimension. While the postcolonial text does address cross cultural relations thematically in order to assert the otherness of non-European cultures, it is mainly through its language - a language that entwines the familiar with the unfamiliar, the European with the non-European - that the text makes its transformative impact upon both the writer and the reader. In the case of postcolonial Anglophone literature, the language is English but English modified by the writer to express cultural difference. To illustrate this point, Ashcroft gives the example of Chinua Achebe's use of English in his novel Things Fall Apart. According to him, "The Igbo is transformed into English, but the English is transformed by the Igbo cadence - the language might be English but the cultural resonance is Igbo." ${ }^{, 33}$ In Ashcroft's view, the affective force of the postcolonial text arises out of this presence of otherness within the familiar as "the writer carries with him an aesthetic command of the rhythm and tonal cadence of the original language, thus laying stress on metrical regularity and the music of the lines" while writing in English. ${ }^{34}$ This estrangement of both the writer and the reader from their familiar cultures and languages brings them closer to each other as it unsettles their close connection and association with one culture and opens them up to the presence and acknowledgement of others.

The meaning of the term "affect" is, therefore, central to Ashcroft's conceptualization of postcolonial aesthetics. For Ashcroft, "affect" seems to mean to touch the feelings of someone or to move a person emotionally. However, "affect" is also used to mean to pretend and to act or behave in a way to make an impression upon others. Critical opinion both within and outside of postcolonial theory is divided on which of these two meanings of "affect" accurately defines postcolonial literature. While a number of critics have highlighted how postcolonial literature makes a deep emotional impact upon readers and leads to greater acceptance of cultural diversity and greater awareness of injustice and inequality, a significant number of critics have also expressed their suspicion of, if not an outright disapproval of, what they describe as a deliberate and crafted exoticism of postcolonial literature. In other words, postcolonial literature can be characterized in two ways: as a literature of affection, expressing a genuine attachment to a culture and to a

\footnotetext{
${ }^{30}$ Ibid., p. 335 .

${ }^{31}$ Ibid., p.337.

${ }^{32}$ Ibid.

${ }^{33}$ Ashcroft, Op.Cit. p.415.

${ }^{34}$ Ibid.
} 
people, and as a literature of affectation, pretending to represent a culture and its norms but actually indulging in exoticism. The difference and the significance of the difference between affection and affectation in relation to postcolonial literature will be elaborated in the following paragraphs.

Graham Huggan in his book The Postcolonial Exotic has discussed this matter at length. Huggan has accurately characterized the alleged exoticism of postcolonial literature as more of a "dilemma" than a "diversionary tactic." 35 According to Huggan, the questions that comprise this dilemma are: "is it possible to account for cultural difference without at the same time mystifying it? To locate and praise the other without also privileging the self? To promote the cultural margins without ministering to the needs of the mainstream? To construct an object of study that resists, and possibly forestalls, its own commodification?"36 Huggan suggests that exoticism, instead of being exclusively suggestive of complicity and pretension, can be seen as a strategic tool in the hands of the postcolonial writer. In Huggan's view, a "strategic exoticism" can become "the means by which postcolonial writers/thinkers, working from within exoticist codes of representation, either manage to subvert those codes ... or succeed in redeploying them for the purpose of uncovering differential relations of power." ${ }^{37}$ Huggan's idea is that exotic material in postcolonial literature cannot be dismissed simply as a marketing strategy by which postcolonial writers exploit their cultural identity and background to sell their products. Instead, the function of exotic cultural material within specific postcolonial texts should be analyzed to see if it serves an aesthetic purpose or just an anthropological one. In other words, it is important to distinguish the literature of affection from the literature of affectation, or, better still, the interplay of affection and affectation in specific postcolonial texts.

\section{Affect, Affection, or Affectation?}

As Ashcroft's comments cited above suggest, Achebe's novel Things Fall Apart has remained at the centre of such debates about authentic cultural representation and exoticism in postcolonial literature. Huggan has also discussed this novel in relation to what he calls the "anthropological exotic". ${ }^{38}$ To make my argument regarding conceptualization of postcolonial aesthetics, I will take up the discussion of another novel which has received similar critical attention: Ahmed Ali's Twilight in Delhi. I will refer to Hasan Askari's commentary on this novel to illustrate how the difference between affection and affectation can help us in determining the aesthetic value of postcolonial texts and in developing the concept of postcolonial aesthetics.

In his essay "A Novel by Ahmed Ali" Askari identifies two different purposes at work in Ali's novel, which he calls the literary and the non-literary purposes. However, he clarifies that this does not mean that there are inner contradictions in the novel. The literary and the non-literary purposes can be present in a novel without any contradiction. In fact, the non-literary purpose can even become a motivation for artistic creation. ${ }^{39}$ Askari claims that the primary purpose of Ali's novel was non-literary and he satirically describes this purpose as Ali's intention to produce "a guide to Delhi for Englishmen." 40 The rich cultural details present in the novel suggest that the novel is written for a foreign reader as the local reader finds these details boring and unnecessary. Robert Young, too, has criticized the presence of these details in the novel. According to Young, "An awful lot of that book [Twilight in Delhi] is taken up by an account, not in anthropological

\footnotetext{
${ }^{35}$ Graham Huggan, The Postcolonial Exotic: Marketing the Margins, (London and New York: Routledge, 2001), p.31.

${ }^{36}$ Ibid., pp.31-32.

${ }^{37}$ Ibid., p. 32

${ }^{38}$ Ibid., pp.41-44

${ }^{39}$ Muhammad Hasan Askari, "A Novel by Ahmed Ali," Trans. Carlo Coppola. Annual of Urdu Studies 9 (1994), p.30.

${ }^{40}$ Ibid.
} 
language of course but a descriptive account, of the social institutions of Muslim culture." ${ }^{41}$ Young acknowledges that Achebe's novel too has lots of cultural details but he justifies these details by saying that they are tied to the political purpose of the novel. In Askari's view, the cultural details in Twilight in Delhi, though intended to inform English readers about Indian Muslim culture, are not extraneous to but are essential for the novel's literary purpose.

Askari defines Ali's literary purpose in Twilight in Delhi as the desire to represent the collective life of the Delhi Muslim community. The challenge before the writer in writing such a 'collective' novel is that the life of the community is to be represented "in the mirror of everyday life where no extraordinary or exciting events take place" without letting these informative details affect the artistic and technical quality of the novel. ${ }^{42}$ Ali has tried to portray the day-to-day life of the Delhi Muslim community and this life consists of "simple and insignificant" things like "eating, drinking, sleeping, festivals and fairs, marriage, birth, death, naïve love affairs, quarrels and arguments." ${ }^{43}$ However, these details, which Young finds tedious and boring, have been given a "fundamental and universal significance" in the novel. ${ }^{44}$ Since Ali's purpose is to depict the collective life of the community, the function of details is not simply informative but aesthetic. According to Askari

Within these details are embedded the spirit of collective life and the values of collective unity. It is through these insignificant details that we come to know collective life and the soul of society, which is its subject. These details, therefore, are as essential for the artistic purpose of the book as they are for the non-artistic ones. ${ }^{45}$

The details of the social life of the Muslim community are represented with affection and attachment and are not included simply for the sake of information. As Askari states, Ali does not hide his love for the values of the Delhi Muslim culture even when he was aware that these values were no longer stable and permanent. In fact, Ali has analyzed the defeat and decay of the Delhi Muslim culture "with great courage and honesty" and has not allowed his lover for that culture to overwhelm his artistic balance and integrity (32).

One particular evidence of Ali's artistic success in the writing of Twilight in Delhi is his use of the English language. In writing the novel Ali faced the challenge faced by every postcolonial writer who aims to represent his or her native culture in a foreign language. This challenge is described by Raja Rao, one of the pioneers of Indian writing in English, as the need "to convey in a language that is not one's own the spirit that is one's own". 46 According to Askari, "The problem the author faced in this context was to create a style which, being English, was not English and at the same time adequate to transfer the atmosphere and harmony of life in Delhi into a foreign language, even though he had to twist and turn it to suit his purpose." 47 In Askari's view, "Ahmed Ali has been most successful in this endeavor and has made a foreign language subservient to his artistic will." 48 So successful is Ali's use of the English language in depicting the Indian Muslim culture that, according to Zahra Sabri, a reader does not even need to translate the language into Urdu for understanding the meaning. The very tone and cadence of the language carries the meaning within it. Sabri states, "And you do not even have to translate as you read, you can just feel the meaning." 49 Thus, the cultural difference of the

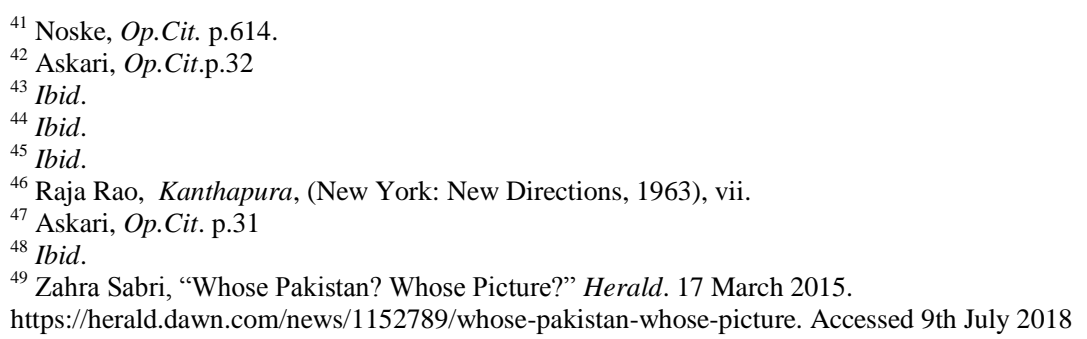


novel is carried and embodied in the language of the novel and is not just represented in it.

What Askari's commentary on Ali's novel emphasizes is that the socio-cultural, ethnographic or anthropological element in a postcolonial novel is not a blemish on the novel when it is subservient to or fused with the aesthetic aspect of the novel. In other words, the form and content of the novel have to be fused together for the novel to be successful. This is a rather clichéd claim associated mainly with the Anglo-American formalist school of literary criticism which for long has been sidelined in literary studies. Literary studies today are dominated by sociological, psychological and political approaches. However, aesthetics and formalism are making a strong come back in literary studies today. Several books on the theme of the return of aesthetics and on "new formalism" have been published recently. These books attempt to redefine the aesthetic and formalist approaches to literary and other artistic works. The importance of aesthetics is being acknowledged even by such strong critics of aesthetics as Terry Eagleton whose The Ideology of the Aesthetic (1990) is recognized as one of the strongest critiques of aesthetics. In such recent books as How to Read Literature (2013) and How to Read a Poem (2007), Eagleton has emphasized the importance of reading literature closely and has expressed his disappointment at the decline of close reading skills among both students and teachers of literature. The importance being given to aesthetics in postcolonial theory, then, is part of a larger shift in literary studies towards aesthetics and formalism and away from sociological and political approaches.

\section{Conclusions}

From this discussion it may be concluded that with the increasing emphasis on aesthetic and formal aspects of literary texts in literary criticism today, critics and theorists of postcolonial literature too are attempting to define the aesthetic dimension of postcolonial texts. Their concern is to develop a specifically postcolonial aesthetics and not to endorse a universal aesthetics. The idea of universality of aesthetics arouses suspicion and hostility among postcolonial critics as this idea for them is highly Eurocentric and ideological. In fact, it was against this idea of universal aesthetics that postcolonial literature had to battle against in order to make room for itself in the world of literature. However, the challenge in developing a postcolonial aesthetics is to make it open and inclusive of all the diverse literary traditions that make up postcolonial literature.

This article has proposed a way of evaluating the aesthetic dimension of postcolonial texts by applying the criteria of affection and affectation. This criteria is most relevant to texts that claim to or are claimed to represent cultural identity and difference. This method of aesthetic evaluation is cognizant of the fact that different postcolonial writers use different styles according to their own literary and non-literary concerns. A writer like VS Naipaul writes in a traditional literary style and yet is very effective in making the desired impact upon the reader. Derek Walcott uses a variety of styles in accordance with the mood and direction of each of his literary works. Vikram Seth from India also uses a traditional literary style and is yet considered a successful Indian writer writing in English. Mohsin Hamid from Pakistan uses an informal style of writing in accordance with the narrative voice he adopts in his novels while Musharraf Ali Farooqui uses a more formal and poetic style for writing his novels. The only thing that matters is that the style suits the subject and theme and should not be seen as artificial and deliberate. There are plenty of postcolonial novels in English which are littered with non-English words and phrases, neologisms and stylistic innovations so as to highlight cultural difference. However, all this creativity amounts to is nothing but a very conventional form of exoticism relying upon an affectation of cultural difference.

The postcolonial writers do not represent their cultural affiliations and attachments by deliberately and artificially adopting strange literary styles but rather do so by selecting and using a style that embodies their central concerns in their novels. The 'material 
resonance' of their texts arises out of their affectionate attachment to the worlds and cultures they represent and their intense struggle against oppression and injustice. It does not arise out of a clever but artificial linguistic creativity that constitutes an affectatious display of cultural identity and difference. Thus, the postcolonial aesthetic may be defined in relation to the difference between affection and affectation in postcolonial texts.

\section{Bibliography}

Achebe, Chinua. "Colonialist Criticism." Critical Theory Since Plato. Ed. Hazard Adams. Orlando, Florida: Harcourt Brace and Jovanovich, 1992.

Achebe, Chinua. Things Fall Apart. London: Penguin Books Ltd., 2001.

Ashcroft, Bill. "Towards a Postcolonial Aesthetics." Journal of Postcolonial Writing 51, no. 4 (2015): 410-421.

Askari, Muhammad Hasan. "A Novel by Ahmed Ali." Trans. Carlo Coppola. Annual of Urdu Studies 9 (1994): 27-38.

Bertacco, Simona. "Postcolonialism." In The Oxford Handbook of Philosophy and Literature, edited by Richard Eldridge. New York: Oxford University Press, 2009 [Paperback Edition 2013], 322-346.

Boehmer, Elleke. "Questions of Neo-Orientalism." Interventions: International Journal of Postcolonial Studies 1, no. 1 (1998): 18-21.

Boehmer, Elleke. "A Postcolonial Aesthetic: Repeating Upon the Present." In Rerouting the Postcolonial: New Directions for the New Millennium, edited by Janet Wilson, Cristina Sandru and Sarah Lawson Welsh. London and New York: Routledge, 2010, 170181.

Huggan, Graham. The Postcolonial Exotic: Marketing the Margins. London and New York: Routledge, 2001.

Noske, Catherine. "A Postcolonial Aesthetic? An Interview with Robert Young." Journal of Postcolonial Writing 50, no. 5 (2014): 609-621.

Rao, Raja. Kanthapura. New York: New Directions, 1963.

Sabri, Zahra. "Whose Pakistan? Whose Picture?" Herald. 17 March 2015. https://herald.dawn.com/news/1152789/whose-pakistan-whose-picture. Accessed 9 July 2018.

Young, Robert. “Postcolonial Remains.” New Literary History, 43, no. 1 (2012): 19-42. 